\title{
DAYA HAMBAT EKSTRAK ETANOL Schismatoglottis sp. TERHADAP BAKTERI Staphylococcus aureus dan Escherichia coli
}

\author{
Fahri Bian ${ }^{1)}$, Febby E.F. Kandou ${ }^{1)}$,Marhaenus J. Rumondor ${ }^{1)}$ \\ ${ }^{1)}$ PS Biologi FMIPA Universitas Sam Ratulangi Manado \\ e-mail :Brown_minhoz@yahoo.com; febbyefkandou@yahoo.com; \\ marhaenusrumondor66@yahoo.com
}

\begin{abstract}
ABSTRAK
Penelitian ini bertujuan untuk mengetahui daya hambat ekstrak etanol daun Schismatoglottis sp. terhadap bakteri Staphylococcus aureus dan Escherichia coli. Daya hambat ekstrak etanol Schismatoglottis sp. terhadap bakteri menggunakan metode Kirby-Bauer, yaitu metode difusi dengan cakram kertas. Ekstrak etanol Schismatoglottis sp. menghambat pertumbuhan S. aureus pada konsentrasi $60 \%$ dan $90 \%$ dengan diameter zona hambat $16,10 \mathrm{~mm}$ dan $31,33 \mathrm{~mm}$ serta terhadap E. coli pada konsentrasi 30\%, 60\%, dan 90\% dengan diameter zona hambat berturutturut $11,72 \mathrm{~mm}, 16,38 \mathrm{~mm}$, dan $29,27 \mathrm{~mm}$. Berdasarkan hasil penelitian, dapat disimpulkan bahwa ekstrak etanol Schismatoglottis sp. terhadap S. aureus pada konsentrasi $60 \%$ dan $90 \%$ masing-masing memiliki kekautan antibakteri termasuk kategori kuat dan sangat kuat, sedangkan terhadap E. coli pada konsentrasi $30 \%$ dan $60 \%$, memiliki kekuatan antibakteri kategoti kuat sedangkan pada konsentrasi $90 \%$ memiliki kekuatan antibakteri kategori sangat kuat.
\end{abstract}

Kata kunci : Schismatoglottis sp, Antibakteri, Staphylococcus aureus, Escherichia coli

\section{THE INHIBITION OF ETHANOL EXTRACT OF Schismatoglottis sp. AGAINST BACTERIA Staphylococcus aureus AND Escherichia coli.}

\begin{abstract}
This study aimed to determine the inhibition of ethanol extract of leaves Schismatoglottis sp. against $S$. aureus and E. coli. Inhibition of the ethanol extract of Schismatoglottis sp. against to bacterial using the Kirby-Bauer method, is the paper disk diffusion method. Schismatoglottis sp. ethanol extract inhibit the growth of S. aureus at a concentration of $60 \%$ and $90 \%$ inhibition zone with a diameter of $16.10 \mathrm{~mm}$ and $31.33 \mathrm{~mm}$ and against $E$. coli at a concentration of $30 \%, 60 \%$, and $90 \%$ with inhibition zone diameter respectively $11,72 \mathrm{~mm}, 16.38 \mathrm{~mm}$ and $29.27 \mathrm{~mm}$. Based on the results, it can be concluded that the ethanol extract Schismatoglottis sp. against S. aureus at concentrations of $60 \%$ and $90 \%$ respectively have antibacterial kekautan categorized as strong and very strong, while against E. coli at a concentration of $30 \%$ and $60 \%$, have a strong kategoti antibacterial strength while at a concentration of $90 \%$ has antibacterial strength very strong category.
\end{abstract}

Keywords: Schismatoglottis sp, antibacterials, Staphylococcus aureus, Escherichia coli.

\section{PENDAHULUAN}

Suku Araceae atau keluarga talastalasan merupakan salah satu golongan tumbuhan yang memiliki tingkat keanekaragaman yang cukup tinggi dan mempunyai daerah persebaran yang luas di wilayah Indonesia.

Salah satu tumbuhan yang memiliki khasiat sebagai obat tradisional, ialah tumbuhan talas-talasan. Di beberapa negara tumbuhan talas-talasan dimanfaatkan sebagai obat antiinflamasi, antikanker, antidiabetes, dan antibakteri, (Prajapati et al., 2011). Senyawa-senyawa yang telah berhasil diisolasi dari daun Colocasia esculanta mengandung senyawa kimia flavonoid, tanin, alkaloid, dan saponin (Wijaya, 2014). Di antara suku Araceae terdapat jenis Schismatoglottis sp. yang banyak terdapat di Sulawesi Utara, tetapi belum ada penelitian 
yang membuktikan pengaruhnya terhadap bakteri E. coli dan S. aureus. Untuk menguji kemampuan suatu senyawa yang bersifat antibakteri biasanya menggunakan bakteri $S$. aureus dan E. coli. Kedua bakteri ini dipilih, untuk mewakili bakteri kelompok Gram positif ( $S$. aureus) dan kelompok Gram negatif(E.coli).

\section{METODE PENELITIAN}

\section{Tempat dan Waktu Penelitian}

Penelitian ini dilaksanakan di Laboratorium Mikrobiologi (pembuatan ekstrak), Laboratorium Bioteknologi (uji aktivitas antibakteri), serta Laboratorium Farmakologi dan Biofarmasi (evaporasi ekstrak) di Fakultas Matematika dan Ilmu Pengetahuan Alam Universitas Sam Ratulangi Manado pada bulan Maret-Juli 2015.

\section{Alat dan Bahan}

Alat-alat yang digunakan, yaitu Erlenmeyer $500 \mathrm{ml}$, gelas ukur $500 \mathrm{ml}$, aluminium foil, timbangan digital, 10 tabung reaksi, 20 cawan petri, hot plate, laminar air flow, lampu bunsen, jarum inokulasi lurus, autoklaf, lemari pendingin, mortar dan pestle, rak tabung, korek api, pinset, evaporator, oven, cakram kertas jenis Whatman No.42 dengan diameter $6 \mathrm{~mm}$, mistar, kamera, sarung tangan, mikropipet $(10-100 \mu \mathrm{L})$.

Bahan-bahan yang digunakan yaitu daun Schismatoglottis sp. biakan murni bakteri S. aureus dan E. coli yang diperoleh dari Laboratorium Bioteknologi FMIPA Unsrat, medium Nutrient Agar (NA), medium Nutrient Broth (NB), akuades, etanol 96\%, dan zat antibiotik (ampicillin).

\section{Penyiapan Sampel dan Pembuatan Ekstrak \\ Daun Schismatoglottis sp. diambil dicuci bersih, diiris daunnya,} dikeringanginkan di dalam ruangan selama \pm 15 hari sampai mencapai berat konstan, kemudian diblender daunnya serta ditapis hingga menjadi serbuk (Dewi, 2010). serbuk ditimbang sebanyak $50 \mathrm{~g}$ kemudian dimasukan ke dalam wadah dan dimaserasi dengan pelarut etanol $96 \%$, sebanyak $500 \mathrm{ml}$ selama 3 x 24 jam. Larutan disaring mengunakan kain sifon dan kertas Whatman kemudian dimasukkan ke dalam gelas erlenmeyer untuk dipisahkan residu dari filtrat (Frengki et al., 2014), filtrat kemudian diuapkan dengan mengunakan vacum rotary evaporator pada suhu $40^{\circ} \mathrm{C}$ sampai diperoleh ekstrak etanol yang pekat. Ekstrak etanol pekat lalu diuapkan di dalam oven dengan suhu $40^{\circ} \mathrm{C}$ sampai kering atau $1 \times 24$ jam. Ekstrak kemudian diencerkan masing-masing menjadi 30\%, 60\%, dan 90\%. Antibiotik pembanding yaitu ampicillin dibuat dengan takaran $10 \mathrm{mg}$ yang dilarutkan dalam $10 \mathrm{ml}$ akuades (Tangapo, 2005).

\section{Pembuatan Medium Tumbuh Bakteri dan Pembiakan Bakteri}

Dilarutkan $150 \mathrm{ml}$ akuades dengan $1,95 \mathrm{~g}$ medium NB dan $7 \mathrm{~g}$ medium NA dilarutkan dengan $350 \mathrm{ml}$ akuades. Semua campuran medium dipanaskan hingga semuanya larut. Medium NB dimasukan ke dalam 10 tabung reaksi masing-masing sebanyak $10 \mathrm{ml}$ dan medium NA untuk disterilisasi dengan autoklaf selama 15 menit pada suhu $121^{\circ} \mathrm{C}$ di bawah tekanan $15 \mathrm{lbs}$ (Dewi, 2010). Bakteri Staphylococcus aureus dan Escherichia coli yang dijadikan biakan murni, diinokulasikan secara aseptik ke medium NB steril yang berisi $10 \mathrm{ml}$, masingmasing sebanyak 5 tabung reaksi dari 10 tabung NB steril yang sudah disiapkan. Biakan tersebut sebagai stocklalu diinkubasikan selama 1x 24 jam pada suhu $37^{\circ} \mathrm{C}$ (Ramadanti, 2008).

\section{Daya Hambat Ekstrak terhadap Bakteri}

Bakteri S. aureus dan E. coli sebagai biakan uji, dipindahkan dari medium NB ke 10 cawan petri steril masing-masing sebanyak $0,1 \mathrm{ml}$ (Tangapo, 2005). Medium NA dituang kecawan petri berisi biakan uji, masing-masing sebanyak $15 \mathrm{ml}$. Masingmasing dari cakram kertas steril dipindahkan secara aseptik menggunakan pinset steril ke konsentrasi yakni, 30\%, 60\%, dan 90\% serta larutan antibiotik (kontrol positif) dan larutan akuades (kontrol negatif) direndam \pm 1 menit (Tangapo, 2005). Cakram kertas kemudian dipindahkan dengan pinset steril ke medium NA berisi $S$. aureus dan E. coli secara aseptik, kemudian diinkubasi selama 1 x 24 jam dengan suhu $37^{\circ} \mathrm{C}$. Setelah diinkubasi, diamati zona bening yang terdapat di sekitar kertas cakram dan diukur diameternya. Pengujian daya hambat antibakteri ekstrak etanol daun Schismatoglottis sp. terhadap S. 
aureus dan E. coli dilakukan sebanyak tiga kali pengulangan untuk setiap konsentrasi yang diuji (Tangapo, 2005).

\section{Analisis Data}

Diameter zona daya hambat ekstrak etanol daun Schismatoglottis sp terhadap S. aureus dan E. coli disajikan dalam bentuk tabel dan gambar. Efektivitas antibakteri konsentrasi ekstrak etanol daun Schismatoglottis sp. terhadap antibiotik dihitung berdasarkan persamaan (Tangapo, 2005), yaitu:

$$
E=(D / D a) \times 100 \%
$$

Keterangan :

E : efektivitas antibakteri (\%)

D:diameter zona hambat ekstrak (mm)

Da:diameter zona hambat antibiotik (mm)

\section{HASIL DAN PEMBAHASAN}

\section{Daya Hambat Ekstrak}

Pengukuran diameter zona hambat dilakukan untuk menggolongkan kekuatan antibakteri. Zona bening yang terdapat disekitar cakram kertas yang diuji menandakan bahwa terjadi aktivitas daya hambat. Adanya zona bening disekitar cakram kertas merupakan daerah difusi dalam mempengaruhi pertumbuhan bakteri. Kekuatan antibakteri dapat diketahui dengan mengukur besarnya diameter dari zona hambat yang terbentuk oleh ekstrak yang diuji. Davis dan Stout, (1971) mengelompokkan kekuatan antibakteri dalam menggolongkan diameter dari zona hambat yang diperoleh.

\section{Ekstrak Daun Schismatoglottis sp.}

Hasil pengujian dari ekstrak etanol Schismatoglottis sp. terhadap bakteri E coli, terlihat memiliki zona bening di konsentrasi 30\%, 60\%, dan 90\% (Gambar 1). Diameter daya hambat ekstrak etanol Schismatoglottis sp. terhadap E. coli semakin meningkat bersamaan dengan meningkatnya konsentrasi ekstrak (Tabel 1). Hal ini menunjukkan bahwa senyawa aktif yang terdapat didalam ekstrak etanol Schismatoglottis sp. memiliki aktivitas antibakteri dan mampu menghambat pertumbuhan bakteri $E$. coli dari golongan Gram negatif. Daya hambat ekstrak etanol Schismatoglottis sp. terhadap bakteri E. coli pada konsentrasi $30 \%$ dan $60 \%$ memiliki kekuatan antibakteri yang termasuk kategori kuat, sedangkan pada konsentrasi 90\% memiliki kekuatan antibakteri kategori sangat kuat karena mempunyai diameter diatas 20 $\mathrm{mm}$.

Tabel 1. Diameter Zona Hambat Ekstrak Schismatoglottis sp terhadap S. aureus dan E.

\begin{tabular}{clc}
\hline $\begin{array}{c}\text { Konsentrasi } \\
(\%)\end{array}$ & $\begin{array}{l}\text { Diameter Zona Hambat } \\
\text { Ekstrak Schismatoglottis } \\
\text { sp(mm) }\end{array}$ \\
\cline { 2 - 3 } & S. aureus & E. coli \\
& & \\
\hline $30 \%$ & $0,00 \pm 0,00$ & $11,72 \pm 0,69$ \\
$60 \%$ & $16,10 \pm 0,77$ & $16,38 \pm 0,76$ \\
$90 \%$ & $31,33 \pm 2,72$ & $29,27 \pm 0,63$ \\
\hline coli. & & \\
\hline
\end{tabular}

Hal ini menunjukkan bahwa senyawa aktif yang terdapat didalam ekstrak etanol Schismatoglottis sp. memiliki aktivitas antibakteri dan mampu menghambat pertumbuhan bakteri E.coli dari golongan Gram negatif. Daya hambat ekstrak etanol Schismatoglottis sp. terhadap Bakteri E. coli pada konsentrasi 30\% dan 60\% memiliki kekuatan antibakteri yang termasuk kategori kuat, sedangkan pada konsentrasi 90\% memiliki kekuatan antibakteri kategori sangat kuat karena mempunyai diameter diatas 20 $\mathrm{mm}$. Hasil yang sama juga ditunjukkan dari ekstrak etanolSchismatoglottis sp terhadap bakteri S.aureusdari golongan Gram positif.Diameter daya hambatdari ekstraketanol Schismatoglottis sphanya terlihat pada konsentrasi $60 \%$ dan $90 \%$, sedangkan pada konsentrasi 30\% tidak terlihat zona bening (Gambar 2). Hal ini menujukkan bahwa ekstrak etanol Schismatoglottis sp. pada konsentrasi sedang dan tinggi, sudah mampu menghambat metabolisme bakteri $S$. aureus, sedangkan pada konsentrasi rendah belum mampu mempengaruhi metabolisme bakteri. Hal ini terlihat dengan adanya pertumbuhan bakteri di sekitar cakram kertas pada konsentrasi $30 \%$. Nilai diameter dari zona hambat ekstrak etanol Schismatoglottis sp. terhadap S. aureus pada konsentrasi $60 \%$ dan $90 \%$ adalah 16,10 $\mathrm{mm}$ dan 31,33 $\mathrm{mm}$ (Tabel 1). Daya hamba tekstrak etanol Schismatoglottis sp. terhadap bakteri S. aureus pada konsensentrasi 60\% termasuk dalam kategori kuat, sedangkan pada konsentrasi 90\% termasuk dalam kategori sangat kuat karena mempunyai 
diameter diatas $20 \mathrm{~mm}$. Adanya peningkatan zona bening pada bakteri E.coli dan $S$. aureus, disebabkan oleh senyawa aktif yang terkandung dalam ekstrak etanol daun Schismatoglottis sp. yang mampu membunuh biakan uji. Menurut Lense (2011), daun dari Schismatoglottis sp. mengandung senyawa alkaloid. Senyawa alkaloid memiliki potensi sebagai antibakteri (Nakade et al.,2013). Hal inilah yang menjadi dasar adanya zona bening yang ditunjukan oleh ekstrak etanol Schismatoglottis sp. terhadap bakteri $S$. aureus dan E. coli.

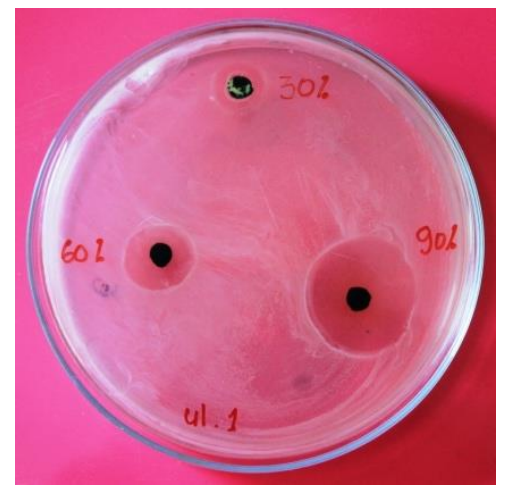

Gambar 1. Zona Hambat Ekstrak Daun Schismatoglottis sp pada E. coli pada Konsentrasi 30\%, 60\%, dan 90\%.

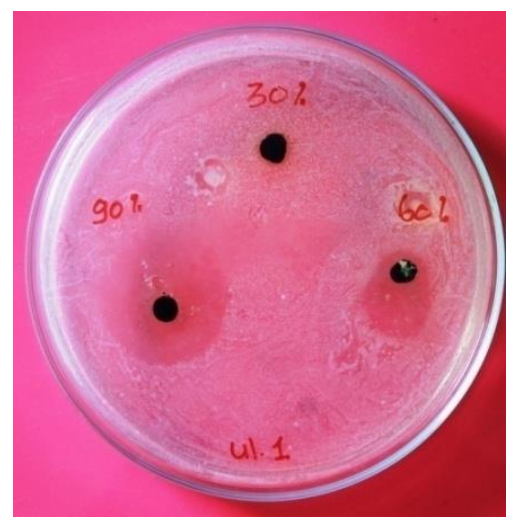

Gambar 2. Zona Hambat Ekstrak Daun Schismatoglottis sp. pada $S$. aureus pada Konsentrasi 30\%, 60\%, dan 90\%.

\section{KESIMPULAN}

Berdasarkan hasil penelitian maka dapat disimpulkan bahwa pengujian ekstrak etanol daun Schismatoglottis sp. terhadap E. coli dan $S$. aureus menunjukkan adanya aktivitas antibakteri. Zona hambat ekstrak etanol daun Schimatoglottis sp. pada konsentrasi $30 \%$ dan $60 \%$ memiliki daya hambat yang tergolong kuat, serta pada konsentrasi $90 \%$ memiliki daya hambat yang tergolong sangat kuat terhadap bakteri $E$. coli, sedangkan pada konsentrasi $60 \%$ memiliki kekuatan antibakteri tergolong kuat serta pada konsentrasi $90 \%$ memiliki kekuatan antibakteri kategori sangat kuat terhadap bakteri $S$. aureus.

\section{SARAN}

Perlu dilakukan penelitian lanjutan untuk mengetahui senyawa bioaktif yang terkandung di dalam Schismatoglottis sp yang lebih khusus, karena memiliki senyawa antibakteri dan uji daya hambat terhadap bakteri lain.

\section{DAFTAR PUSTAKA}

Adam, A. A. 2014. Aktivitas Antibakteri Ekstrak Kasar Tunikata Polycarpa aurata terhadap Streptococcus mutans. [Skripsi]. Universitas Sam Ratulangi Manado. Manado.

Davis, W. W dan T. R. Stout. 1971. Disc Plate Method of Microbiological Antibiotic Essay. Journal of Microbiology 22(4): 659-665.

Dewi, F. K. 2010. Aktivitas Antibakteri Ekstrak Etanol Buah Mengkudu (Morinda citrifolia) terhadap Bakteri Pembusuk Daging Segar. [Skripsi]. Universitas Sebelas Maret. Surakarta.

Frengki, Roslizawaty dan D. Pertiwi. 2014. Uji Toksisitas Ekstrak Etanol Sarang Semut Lokal Aceh (Mymercodia sp.) dengan Metode BSLT terhadap Larva Udang Artemia salina Leach. Jurnal Medika Viterinaria 8(1): 0853-194.

Lense, O. 2011. Biological Screening of Selected Traditional Medicinal Plants Species Utilized by Local People of Manokwari, West papua Province. Nusantara Bioscience 3(3): 145-150.

Pattaratanawadee, E., C. Rachtanapun., P. Wanchaitanawong dan W. Mahakarnchanakul.2006.Antimicrobial Activity of Spice Extracts against Pathogenic and Spoilage Microorganisms. Kasetsart journal: Natural Science 40(5): 159-165.

Ramadanti, I. A. 2008. Uji Aktivitas Antibakteri Ekstrak Bawang Putih (Allium sativum L)terhadap bakteri Escherichia coli in vitro. [Artikel Karya Tulis Ilmiah].Universitas Diponegoro. Semarang. 
Rezvanpanah, S., K. Rezaei.,M.T. Golmakani dan S. H. Razavi. 2011. Antibacterial Properties and Chemical Characterization of the Essential Oils from Summer Savory Extracted by Microwave-Assisted Hydrodistillation. Braz J Microbiol 4(42): 1453-1462.

Rostinawati, T. 2009. Uji Aktivitas Antibakteri Ekstrak Etanol Bunga Rossela (Hibiscus sabdarifa L.) terhadapEscherichia coli, Salmonella typhi dan Staphylococcus aureus dengan Metode Difusi Agar.[Penelitian
Mandiri]. Universitas Padjadjaran. Jatinangor.

Tangapo. A. M. 2005. Efektivitas Antibakteri Ekstrak Tumbuhan Daun Sendok (Plantago major) terhadap Staphylococcus aureus dan Pseudomonas aeruginosa [Skripsi]. Universitas Sam Ratulangi. Manado 